The second factor is that Orrell's regression coefficient was based on specimens on which either albumin or calcium estimation had been requested, and so would have included some abnormal calcium values not due to protein abnormalities. In our experience true hypocalcaemia is more common than hypercalcaemia. Thus his data would have been weighted with low albumin values associated with relatively higher calcium values from patients with the nephrotic syndrome and with low calcium values with normal albumin values from patients with, for example, osteomalacia. These differences would account both for our higher regression coefficient and for our higher correlation coefficient $(0.867$ on 200 pairs compared with his of 0.720 on 954 pairs: $P<0.001)$. Our intercept at zero albumin concentration $(5.7 \mathrm{mg} / 100 \mathrm{ml})$ is closer to reported values for normal plasma ultrafiltrable calcium (Robertson, 1969; Pedersen, 1970; Rose, 1972) than the intercept calculated from Orrell's (1971) data $(6.8 \mathrm{mg} / 100 \mathrm{ml})$.

Our equation for adjusting calcium concentration by using measurements of albumin

Adjusted calcium $=$ calcium - albumin $+4 \cdot 0$ was based on correction to the mean normal calcium concentration rather than to the mean normal albumin concentration because the between-batch coefficients of variation at normal serum concentrations were $1.2 \%$ for calcium and $3.5 \%$ for albumin, so that we had greater confidence in the accuracy of the mean normal calcium concentration. The adjustment is easily remembered: the measured calcium concentration is increased by $0.1 \mathrm{mg} / 100 \mathrm{ml}$ for every $0.1 \mathrm{~g} / 100$ $\mathrm{ml}$ that the albumin concentration is below $4.0 \mathrm{~g} / 100 \mathrm{ml}$, and vice versa. It should be noted that the adjustment cannot be applied to calcium values on patients with the nephrotic syndrome and hypoalbuminaemia, for the reasons discussed above, nor can it be applied to data from another laboratory if the accuracy and precision of calcium and albumin measurements, and therefore the normal ranges, differ greatly from ours (Payne, 1973).
We conclude that it is impossible to interpret a patient's serum calcium concentration without some measurement of protein concentration, and that any adjustment which is made shou!d be based on albumin rather than total protein or specific gravity.

We are grateful to Dr. Brian Morgan and Dr. Joan Zilva for helpful discussion.

\section{References}

Cockel, R., Kendall, M. J., Becker, J. F., and Hawkins, C. F. (1971). Annals of the Rheumatic Diseases, 30, 166.

Cook, M. G., Levell, M. J., and Payne, R. B. (1970). Fournal of Clinical Pathology, 23, 778 .

Danowski, T. S., et al. (1957). American fournal of Diseases of Children, 93, 604.

Dent, C. E. (1962). British Medical fournal, 2, 1419.

Dent, C. E., and Watson, L. (1968). Lancet, 2, 662 .

Fawcett, J. K., and Wynn, V. (1960). Fournal of Clinical Pathology, 13, 304

Jones, J. H., Peters, D. K., Morgan, D. B., Coles, G. A., and Mallick, N. P.

(1967). Quarterly fournal of Medicine, 36, 301.

Mournal of Laboratory and Clinical Medicine, 73, 825. Sciences, $189,21$.

Orrell, D. H. (1971). Clinica Chimica Acta, 35, 483.

Payne, R. B. (1973). Lancet, 2, 375.

Pedersen, K. O. (1970). Scandinavian fournal of Clinical and Laboratory

Investigation, 25, 223. Scandinavian fournal of Clinical and Laboratory
Pedersen, K. O. (1972). Scan Investigation, 30, 321.

Robertson, W. G. (1969). Clinica Chimica Acta, 24, 149.
Rose, G. A. (1972). Clinica Chimica Acta, 37, 343.

Rushton, M. L., Sammons, H. G., Gosling, P., and Robinson, B. H. B. (1973). Annals of Clinical Biochemistry, 10, 63.

van Leeuwen, A. M., Thomasse, C. M., and Kapteyn, P. C. (1961). Clinica Chimica Acta, 6, 550.

Van Slyke, D. D., et al. (1950). Fournal of Biological Chemistry, 183, 331.

Williams, R. B., Annan, W. Isherwood, D. M. Levell, M. J. and Payne, R. B. (1971). Unpublished observations.

Zilva, J. F., and Pannall, P. R. (1971). Clinical Chemistry in Diagnosis and Treatment, p. 198. London, Lloyd-Luke.

\title{
Dermatoglyphics in Children with Acute Leukaemia
}

\author{
S. G. PURVIS-SMITH, MARGARET A. MENSER
}

British Medical fournal, 1973, 4, 646-648

\section{Introduction}

\section{Summary}

The dermatoglyphics of 135 children with acute leukaemia differed significantly from those of normal controls, and examination of 174 of the patients' first degree relatives indicated that familial factors were involved. The findings suggested that within the racial group studied dermatoglyphics may partly identify a population subgroup which is at increased risk of leukaemogenesis. While these observations may not have immediate clinical application, they are likely to contribute to a greater understanding of individuals who have increased constitutional susceptibility to leukaemia.

\footnotetext{
Children's Medical Research Foundation, Royal Alexandra Hospital for Children, Sydney, Australia

S. G. PURVIS-SMITH, B.sC., Research Assistant

MARGARET A. MENSER, M.D., F.R.A.C.P., Norman Gregg Research Fellow
}

Though there have been a number of apparently conflicting studies on the fingerprints and handprints (dermatoglyphics) of patients with leukaemia (Aleksandrowicz et al., 1966; Kobayashi et al., 1968; Carvalho, 1969; Menser and Purvis-Smith, 1969, 1972; Nora et al., 1969; Rosner, 1969, 1970; Wertelecki et al., 1969, 1973; Stowens and Sammon, 1970; Verbov, 1970; Wittwer and Giessmann, 1970; Zahálková and Běluła, 1970; Berka et al., 1971), careful review of the reports suggests that the dermatoglyphics of children with acute leukaemia deviate fairly consistently from normal. Such findings, if confirmed, may be valuable in identifying populations with increased susceptibility to leukaemogenesis.

\section{Subjects and Methods}

Handprints were obtained from 135 Caucasian children (77 males, 58 females) with a proved diagnosis of either acute lymphatic leukaemia or acute blast cell leukaemia. The patients ranged in age from 4 months to 15 years; the mean age at onset of the disease was 5.26 years in the males and 5.38 years in the females. The patient group included those from earlier studies 
(Menser and Purvis-Smith, 1969, 1972) except for one case of chronic myeloid leukaemia which was omitted. No patient with Down's syndrome was included in the series. In addition to the patients the study included 249 first degree relatives consisting of 113 siblings ( 58 males, 55 females) drawn from 56 families, 76 mothers, and 60 fathers; the parental data thus included 60 parental pairs. Normal controls consisted of 500 randomly chosen Caucasians whose ages ranged from several days to 50 years.

Handprints of all subjects in the study were taken as described previously (Purvis-Smith, 1969) by using the "Faurot" or "Hollister" techniques, and examined for anomalous palmar flexion creases and variations in digital pattern frequencies. The palmar flexion creases were considered to be anomalous if the normal proximal and distal transverse creases were partly or wholly fused into a single transverse palmar crease (simian line) or if the proximal palmar crease extended toward the ulnar margin of the palm past the midline axis of the fifth finger (Sydney line) (Purvis-Smith, 1972). The digital patterns were qualitatively classified as whorls, ulnar loops, radial loops, and arches, and the frequency of each type was noted, but to allow a more quantitative analysis the digital pattern intensity was also calculated for each individual. The pattern intensity index (arrived at by scoring 2 for each whorl pattern, 1 for each loop, 0 for an arch, and then summing the scores for the 10 fingers) takes all pattern types into account and allows comparison of overall digital pattern complexity in the groups under study (Cummins and Midlo, 1961).

The data were statistically analysed by means of the $\chi^{2}$ and Student's $t$ tests.

\section{Results}

The frequencies of anomalous palmar creases and of the four digital pattern types in the patient, parent, and control groups are shown in table I. Analysis of palmar crease frequencies showed that when compared with controls female patients had signifi- cantly more simian creases, while the total number of anomalous creases (simian plus Sydney) was significantly raised in both female patients and their mothers. A familial occurrence of anomalous creases in this disease group is suggested by this increased maternal frequency and a positive association between the incidence of anomalous creases in the leukaemia patients and the incidence in their siblings-38 patients (19 males, 19 females) were paired with a like-sexed sibling and of the 12 patients from this group with either a simian or Sydney line seven had a paired sib with an anomalous crease. Similarly, when 60 patients were matched with their paternal pairs 11 of the 17 patients with anomalous creases had at least one parent with an anomalous palmar crease, an association which was statistically significant $\left(\chi^{2}=6.4 ; \mathrm{P}<0.025\right)$. Of the 38 families with matched siblings $71 \%$ had at least one member (patient, sibling, or parent) with an anomalous crease. This high incidence emphasizes the possibility of the familial occurrence of palmar creases in acute childhood leukaemia, though at present we have insufficient control data to be certain of the incidence of abnormal palmar creases in normal families.

Evaluation of the digital pattern frequencies in table I showed that in comparison with sex matched controls, both male $(P<0.01)$ and female $(P<0.025)$ patients had significantly increased digital pattern complexity (increased frequency of whorl patterns). When compared with controls no significant differences were noted in the patients' mothers, but their fathers had a highly significant $(P<0.005)$ increase in whorl numbers, with a corresponding decrease in the numbers of ulnar loops. The trend towards increased whorl numbers in the patients and their fathers is reflected in their higher digital pattern intensity indices. It is noteworthy that the pattern intensity (and whorl frequency) in the fathers is higher than in the leukaemia patients, suggesting that genetic factors at least partly determine the high whorl frequency in these children.

The relative homogeneity already found in the families of our leukaemia patients is also apparent when the frequencies of palmar creases and digital patterns are compared in the 38 patients and 38 paired siblings (table II). Though the handprints

TABle I-Frequency Data for Anomalous Palmar Creases and Digital Patterns in Patients, Parents, and Controls

\begin{tabular}{|c|c|c|c|c|c|c|c|c|c|c|}
\hline & & & \multicolumn{3}{|c|}{ Palmar Creases* } & \multicolumn{5}{|c|}{ Digital Patterns $\dagger$} \\
\hline & & & Simian & Sydney & $\begin{array}{c}\text { Total } \\
(\text { Simian }+ \text { Sydney })\end{array}$ & W. & U.L. & R.L. & A. & $\begin{array}{c}\text { Average } \\
\text { Pattern Intensity }\end{array}$ \\
\hline $\begin{array}{l}\text { Male : } \\
\text { Patients }(\mathrm{n}=77) \ldots \\
\text { Fathers }(\mathrm{n}=60) \\
\text { Controls }(\mathrm{n}=250)\end{array}$ & $\begin{array}{l}\cdots \\
\cdots\end{array}$ & $\begin{array}{l}\ldots \\
\cdots\end{array}$ & $\begin{array}{l}7(9 \%) \\
7(12 \%) \\
21(8 \%)\end{array}$ & $\begin{array}{c}12(15.5 \%) \\
5(8 \%) \\
24(10 \%)\end{array}$ & $\begin{array}{l}19(24 \cdot 6 \%) \\
12(20 \%) \\
45(18 \%)\end{array}$ & $\begin{array}{r}244 \ddagger(32 \%) \\
197 \S(33 \%) \\
670(27 \%)\end{array}$ & \begin{tabular}{|}
$442 \S(57 \%)$ \\
$339 \S(56.5 \%)$ \\
$1,579(63 \%)$
\end{tabular} & $\begin{array}{r}42(5 \%) \\
42(7 \%) \\
142(6 \%)\end{array}$ & $\begin{array}{r}42(5 \%) \\
22(4 \%) \\
109(4 \%)\end{array}$ & $\begin{array}{l}12 \cdot 62 \\
12 \cdot 91 \\
12 \cdot 24\end{array}$ \\
\hline $\begin{array}{l}\text { Females: } \\
\text { Patients }(n=58) \ldots \\
\text { Mothers }(n=76) \\
\text { Controls }(n=250)\end{array}$ & $\begin{array}{l}. \\
\therefore\end{array}$ & $\begin{array}{l}. \\
\cdots\end{array}$ & $\begin{array}{l}8 \ddagger(14 \%) \\
8(10 \cdot 5 \%) \\
12(5 \%)\end{array}$ & $\begin{array}{l}9(15.5 \%) \\
11(14 \%) \\
21(8 \%)\end{array}$ & $\begin{array}{c}17 \ddagger(29 \cdot 3 \%) \\
19 \ddagger(25 \%) \\
33(13 \%)\end{array}$ & $\begin{array}{r}173 \ddagger(30 \%) \\
180(24 \%) \\
617(25 \%)\end{array}$ & $\begin{array}{r}364(63 \%) \\
501(66 \%) \\
1,614(65 \%)\end{array}$ & $\begin{array}{r}26(4 \%) \\
39(5 \%) \\
119(5 \%)\end{array}$ & $\begin{array}{l}17 \S(3 \%) \\
40(5 \%) \\
150(6 \%)\end{array}$ & $\begin{array}{l}12 \cdot 68 \\
11.84 \\
11.86\end{array}$ \\
\hline
\end{tabular}

*Number and percentage of individuals with each palmer crease.

+Number and percentage of fingers with each pattern type. W. = Whorl. U.L. = Ulnar loop. R.L. = Radial loop. A. = Arch. $\$ \mathrm{P}<0.05$.

Statistical significance by $\mathbf{x}^{2}$ test. Unless marked, frequencies are not significantly different from controls.

TABLE II-Palmar Crease and Digital Pattern Frequencies in 38 Children with Leukaemia Compared with 38 Paired Like-sex Sibs*

\begin{tabular}{|c|c|c|c|c|c|c|c|c|c|c|c|}
\hline & & & & & & \multirow{2}{*}{$\begin{array}{l}\text { Total Palmar Creases } \dagger \\
(\text { Simian }+ \text { Sydney) }\end{array}$} & \multicolumn{5}{|c|}{ Digital Patterns $\ddagger$} \\
\hline & & & & & & & w. & U.L. & R.L. & A. & $\begin{array}{c}\text { Average } \\
\text { Pattern Intensity }\end{array}$ \\
\hline 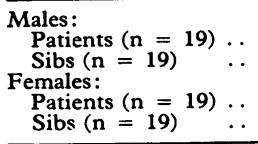 & $\begin{array}{l}\cdots \\
\cdots \\
\cdots\end{array}$ & $\begin{array}{l}\cdots \\
\ldots \\
\cdots\end{array}$ & $\begin{array}{l}\because \\
\cdots \\
\cdots \\
\cdots\end{array}$ & $\begin{array}{l}\cdots \\
\cdots \\
\cdots\end{array}$ & $\begin{array}{l}\cdots \\
\cdots \\
\cdots\end{array}$ & $\begin{array}{l}7 \\
7 \\
5 \\
6\end{array}$ & $\begin{array}{l}62(33 \%) \\
53(28 \%) \\
49(26 \%) \\
49(26 \%) \\
\end{array}$ & $\begin{array}{l}112(59 \%) \\
113(59 \%) \\
129(68 \%) \\
115(60 \cdot 5 \%) \\
\end{array}$ & $\begin{array}{r}14(7 \%) \\
17(9 \%) \\
7(4 \%) \\
9(5 \%) \\
\end{array}$ & 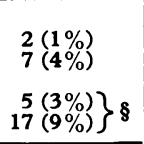 & $\begin{array}{l}13.1 \\
12 \cdot 4 \\
12 \cdot 3 \\
11 \cdot 68\end{array}$ \\
\hline $\begin{array}{l}\text { Total } \\
\text { Patients }(\mathrm{n}=38) \ldots \\
\text { Sibs }(\mathrm{n}=38)\end{array}$ & 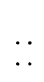 & . & $\begin{array}{l}\cdots \\
\cdots\end{array}$ & $\therefore$ & $\therefore$ & $\begin{array}{l}12 \\
13\end{array}$ & $\begin{array}{l}111(29 \%) \\
102(27 \%)\end{array}$ & $241(63 \%)$ & $\begin{array}{l}21(5 \cdot 5 \%) \\
26(7 \%)\end{array}$ & $\begin{array}{r}7(2 \%) \\
24(6 \%)\end{array}$ & $\begin{array}{l}12 \cdot 7 \\
12 \cdot 0\end{array}$ \\
\hline
\end{tabular}

*Unless marked, differences between patients and sibs are not statistically significant.

+ Number of subjects with an anomalous crease on one or both palms.

Number and percentage of fingers with each pattern type. Abbreviations as in table $I$. $8 \mathrm{P}<0.025$. 
of 113 siblings were available in this study the use only of one like-sex sibling per family ensured equal family representation thus avoiding genetic and sexual bias.

\section{Discussion}

There is now much evidence of an increased frequency of anomalous creases in girls with leukaemia and of an increased frequency of digital whorl patterns in both boys and girls. Why there is no significant change in the incidence of anomalous creases in the boys with leukaemia is not clear, but the new findings of significantly more anomalous creases in the patients' mothers and of significantly more whorls in their fathers suggest that familial factors may contribute towards the dermatoglyphic anomalies in the patients. The probability that genetic factors are involved is enhanced by the finding of relative homogeneity of the patient-sibling groups.

Deviations from normal have been recorded previously in the dermatoglyphics of other groups of leukaemic children, and while some of these deviations have been statistically significant it is important also to examine the trends towards abnormality in the studies where statistical significance was not found or where statistical tests were not applied. Patients were found to have a significantly increased frequency of anomalous palmar creases in several studies (Menser and Purvis-Smith, 1969, 1972; Wertelecki et al., 1969; Zahálková and Běluša, 1970), and in one study (Nora et al., 1969) there was a slight increase in the frequency of these creases. Digital pattern frequencies were also shown to vary from normal in children with acute leukaemia (Menser and Purvis-Smith, 1969, 1972; Wertelecki et al., 1969; Verbov, 1970; Zahálková and Běluša, 1970), the frequency of digital whorl patterns tending to be increased. By using multivariate analysis Stowens and Sammon (1970) claimed to show highly significant differences between the dermatoglyphics of leukaemia patients and controls, though full details of experimental procedure were not given.

Detailed analysis of 76 Caucasian children with acute lymphocytic leukaemia was carried out by Wertelecki et al., (1973). These workers found a significantly raised frequency of both types of abnormal crease in the patients and in their normal siblings, but only simian creases were increased in the parents. The palmar flexion crease findings of these workers were thus similar to our own in suggesting that the raised frequency of abnormal creases in the patients has a familial basis. In their analysis of digital pattern types Wertelecki et al. found a raised whorl frequency in male patients. However, they did not find raised whorl frequencies in female patients or in the patients' fathers. At present the only obvious explanations for these discrepancies are that a smaller number of subjects were studied and unrelated normal controls were not used in their comparisons of digital patterns.

Dermatoglyphic anomalies similar to those found in the children with acute leukaemia have also been documented in the embryopathies resulting from maternal rubella (Purvis-Smith and Menser, 1968; Purvis-Smith et al., 1969) and cytomegalovirus infections (Purvis-Smith et al., 1972; Wright et al., 1972). Examination of the patients' families in these diseases (PurvisSmith et al., 1972; Wright et al., 1972; Purvis-Smith and Menser, 1973) has also shown an increased paternal whorl frequency. These similarities are interesting because of recent reports (Adelstein and Donovan, 1972; Fedrick and Alberman, 1972; Bithell et al., 1973) of increased risk of leukaemia after maternal virus infection during pregnancy. In yet another report (Rose et al., 1972) high maternal whorl frequency has been associated with increased fetal wastage.
The recognition of atypical dermatoglyphic variations in the present series of children with leukaemia and in previous smaller groups (Menser and Purvis-Smith, 1969, 1972; Wertelecki et al., 1969, 1973; Verbov, 1970; Zahálková and Bëuša, 1970) suggests that within the racial group studied the population with these dermatoglyphic traits may be relatively susceptible to leukaemogenesis. There have been many approaches to the problem of defining populations susceptible to leukaemia. Bross and Natarajan (1972) proposed that there were degrees of susceptibility to leukaemia in children exposed in utero to low doses of radiation, and that the children who were at substantially increased risk after prenatal radiation were those with histories of allergy and certain infections. Because childhood leukaemia is comparatively rare, however, there are inherent difficulties in supporting such findings with statistical analysis. These difficulties may partly account for those studies of dermatoglyphics in childhood leukaemia (Rosner, 1969, 1970; Berka et al., 1971) in which differences between patients and controls were not found or were only very slight. Thus while it seems unlikely that dermatoglyphics alone will form a basis for the identification and subsequent protection of leukaemia-susceptible subpopulations, there is every prospect that they will contribute to an understanding of leukaemogenesis and of individuals who have a constitutional susceptibility to this disease.

We thank Dr. A. Tink and the physicians of the Royal Alexandra Hospital for Children, Dr. K. Jones, of the Royal North Shore Hospital, and Dr. D. O'Gorman Hughes, of the Prince of Wales Hospital, for allowing us access to patients under their care. Thanks are also due to the staff of the Haematology Department, Institute of Pathology, Royal Alexandra Hospital for Children.

This study was supported by a grant from the National Health and Medical Research Council of Australia.

Requests for reprints should be addressed to: Mr. S. G. Purvis-Smith, Children's Medical Research Foundation, P.O. Box 61, Camperdown, N.S.W. 2050 Australia.

\section{References}

Adelstein, A. M., and Donovan, J. W. (1972). British Medical fournal, 4, 629. Aleksandrowicz, J., Schiffer, Z., and Debski, T. (1966). Lancet, 2, 1364.

Berka, L., McClure, P. D., Sonley, M. J., and Thompson, M. W. (1971). Canadian Medical Association fournal, 105, 476.

Bithell, J. F., Draper, G. J., and Gorbach, P. D. (1973). British Medical fournal, 1, 706. Bross, I. D. J., and Natarajan, N. (1972). New England fournal of Medicine,
287, 107.

Carvalho, R. I. (1969). Revista Brasileira de Pesquisas Médicas e Biológicas, 2,51 .

Cummins, H., and Midlo, C. (1961). In Fingerprints, Palms and Soles: An Introduction to Dermatoglyphics. New York, Dover.

Fedrick, J., and Alberman, E. D. (1972). British Medical fournal, 2, 485.

Kobayashi, N., Furukawa, T., and Takatsu, T. (1968). Pediatria Universitatis Tokyo, No. 16, 31 .

Menser, M. A., and Purvis-Smith, S. G. (1969). Lancet, 1, 1076.

Menser, M. A., and Purvis-Smith, S. G. (1972). Lancet, 1, 956.

Nora, A. H., Nora, J. J., and Fernbach, D. J. (1969). Lancet, 2, 905.
Purvis-Smith, S. G. (1969). Medical Fournal of Australia, 2, 189.

Purvis-Smith, S. G. (1969). Medical fournal of Australia, 2, 189.

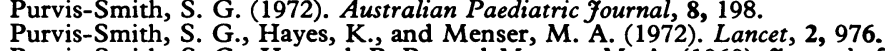

Purvis-Smith, S. G., Hayes, K., and Menser, M. A. (1972). Lancet, 2, 976.
Purvis-Smith, S. G., Howard, P. R., and Menser, M. A. (1969). Journal of the American Medical Association, 209, 1865.

Purvis-Smith, S. G., and Menser, M. A. (1968). Lancet, 2, 141.

Purvis-Smith, S. G., and Menser, M. A. (1973). Paediatric Research, 7, 215.

Rose, L. I., Gabbe, S. G., Teichholz, L. E., Villee, D. B., and Williams, G. H. (1972). New England fournal of Medicine, 287, 451 .

Rosner, F. (1969). Lancet, 2, 272.
Rosner, F. (1970). Lancet, 2, 882.

Stowens, D., and Sammon, J. A. (1970). Lancet, 1, 846

Verbov, J. L. (1970). Fournal of Medical Genetics, 7, 125

Wertelecki, W., Plato, C. C., and Fraumeni, J. F. (1969). Lancet, 2, 806.

Wertelecki, W., Plato, C. C., Fraumeni, J. F. and Niswander, J. D. (1973). Paediatric Research, 7, 620.

Wittwer, B., and Giessmann, H. -G. (1970). Lancet, 1, 425.

Wright, H. T., Parker, C. E., and Mavalwala, J. (1972). California Medicine, 116, 14. 